\title{
NOTE
}

\section{Chroococcoid cyanobacteria: a significant component in the food web dynamics of the open ocean}

\author{
R. Iturriaga \& B. G. Mitchell \\ Department of Biological Sciences, University of Southern California, Los Angeles, California 90089-0371, USA
}

\begin{abstract}
New techniques used during a recent study in the oligotrophic North Pacific Ocean demonstrated that coccoid cyanobacteria were the most abundant photoautotrophs. Despite their small size, they accounted for $64 \%$ of the tota] photosynthesis, with specific growth rates of $1.6 \mathrm{~d}^{-1}$. Grazing experiments indicated that a diverse assemblage of micrograzers is able to consume and effectively metabolize chroococcoid cyanobacteria. In the open ocean, a significant trophic interaction occurs between cyanobacteria and micrograzers, components not included in the classical paradigm of the oceanic food web.
\end{abstract}

In oligotrophic ocean systems, picoplankton (Sieburth et al. 1978) account for approximately $60 \%$ of the inorganic carbon fixation (Li et al. 1983, Platt et al. 1983, Takahashi \& Bienfang 1983) and apparently have high specific growth rates (Bienfang \& Takahashi 1983, Douglas 1984, Landry et al. 1984). Chroococcoid cyanobacteria have been observed in the marine environment (Johnson \& Sieburth 1979, Waterbury et al. 1979), but only recently have they been implicated as a substantial component of the autotrophic picoplankton. Information about cyanobacteria in situ growth rates, photosynthetic characteristics and contribution to higher trophic levels is still limited. Studies conducted with cultures of Synechococcus sp. demonstrated net specific growth rates of up to $1.5 \mathrm{~d}^{-1}$. saturating at low irradiance (Morris \& Glover 1981). Preliminary field data indicate that picoplankton photosynthesis saturates at low irradiance, with maximal contributions to primary production at the base of the euphotic zone (Morris \& Glover 1981, Li et al. 1983, Platt et al. 1983). However, the relative contribution of cyanobacteria to total photosynthesis has not been quantified. Few studies have investigated the cyanobacteria as a food source for grazers. Ingestion of cyanobacteria by protozooplankters has been verified by microscopy (Johnson et al. 1982) and specific grazing rates determined by dilution cultures have been reported for a mesotrophic system (Landry et al. 1984). Protozoa grown in the laboratory on Synechococcus sp. demonstrated their suitability as food for micrograzers, while ingestion, but not digestion, by calanoid copepods has been observed (Johnson et al. 1982).

In the North Pacific gyre $\left(35^{\circ} \mathrm{N}, 128^{\circ} \mathrm{W}\right)$, we studied the distribution and photosynthesis of cyanobacteria and their consumption by micrograzers. This region is typical of the oligotrophic subtropical open ocean in spring, with a mixed layer of 60 to $80 \mathrm{~m}$, and a deep chlorophyll maximum between 90 and $105 \mathrm{~m}$ as shown by in situ profiles of density, fluorescence, and beam attenuation (Fig. 1). Integrated euphotic zone chlorophyll a was approximately $25 \mathrm{mg} \mathrm{m}^{-2}$. Fig. 2 illustrates the vertical distribution of cyanobacteria and acetone extracted chlorophyll a concentrations for discrete samples at the study site. Daily specific growth and grazing rates were calculated from the general exponential relation:

$$
\ln \left(N_{\mathrm{t}} / \mathrm{N}_{0}\right)=\mathrm{xt}
$$

where $\mathrm{N}_{\mathrm{t}}=$ concentration at time $\mathrm{t}_{i} \mathrm{~N}_{0}=$ concentration at time zero; $r=$ specific rate coefficient $; t=$ time. References to rates in this paper are specific natural log rates as defined above. If the cyanobacteria population is in steady state, the specific rate constants for growth, u, grazing, g, and residual losses, l, satisfy the equation: $\mathrm{r}=\mathrm{u}-\mathrm{g}-\mathrm{l}=0$. For our experiments, the loss term, l, includes respiration and exudation by cyanobacteria, respiration and excretion by grazers, and grazers not sampled. A recently published mathematical model implies that microheterotroph respiration may be the dominant loss term required to balance high observed growth rates (Smith et al. 1984).

Primary production of the size fractions was determined by filtering replicate samples of $200 \mathrm{ml}$ onto Millipore HA $(0.45 \mu \mathrm{m})$ filters and Whatman $934 \mathrm{AH}$ 


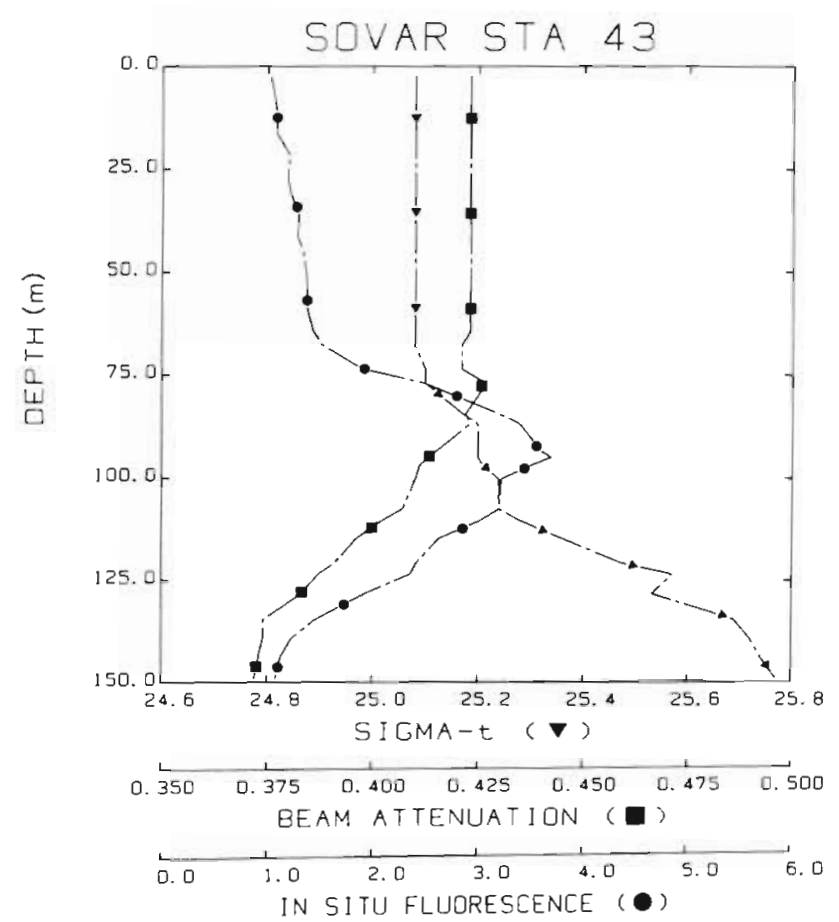

Fig. 1. Vertical profiles of density, fluorescence, and beam attenuation at study site on the eastern edge of the North Central Pacific Gyre $\left(35^{\circ} \mathrm{N}, 128^{\circ} \mathrm{W}\right)$. Data provided by H. Pak of the Optical Oceanography group at Oregon State University

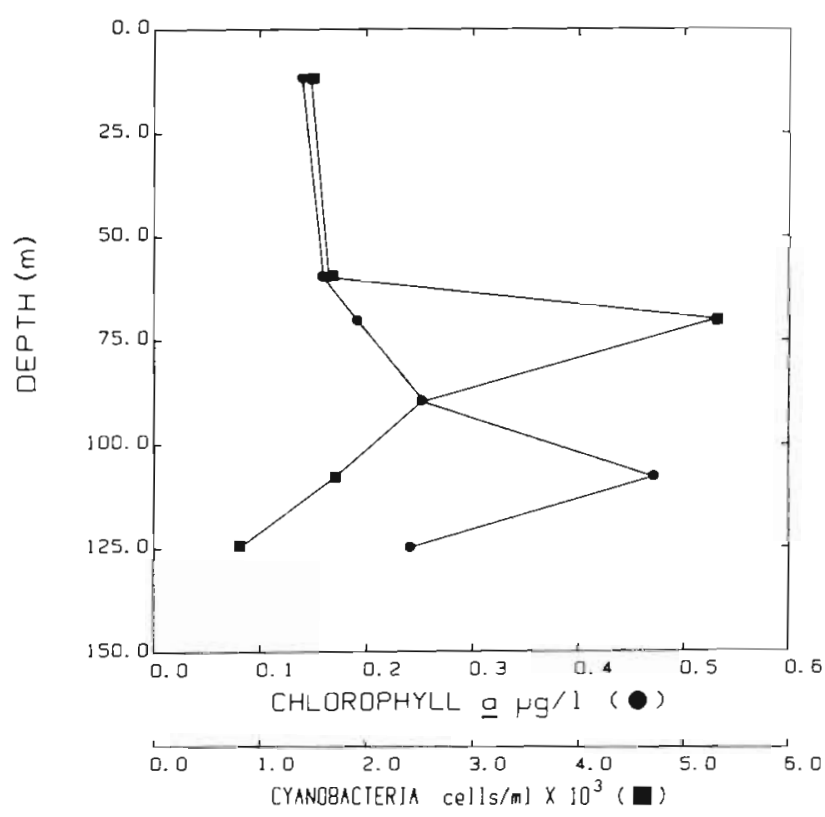

Fig. 2. Vertical distribution for discrete samples of cyanobacteria (epifluorescent direct counts) and total extracted chlorophyll a (retained on Millipore HA filter) at study site. Data represent the means of duplicate samples which had standard errors less than $10 \%$ glass fiber filters, after incubating seawater samples at 5 light levels with $\mathrm{H}^{14} \mathrm{CO}_{3}^{-}$. To minimize physiological stress the samples were fractionated after incubation. Primary production was calculated according to standard techniques (Strickland \& Parsons 1972). Values for carbon fixation in dark bottles were subtracted from values for light bottles. For oligotrophic waters the difference in primary production retained by the 2 filters is predominantly due to coccoid cyanobacteria. This assertion was validated by direct epifluorescent microscopy on subsamples from the water used for primary production determinations. Duplicate samples of whole seawater and Millipore HA or Whatman 934 $\mathrm{AH}$ filtrates were gravity filtered for direct counts onto $0.2 \mu \mathrm{m}$ Nuclepore filters prestained with irgalan black. The volumes filtered for microscopic counts were equivalent to those filtered in the photosynthetic measurements. The counts were done at sea, soon after sample preparation, to minimize problems associated with loss of cellular fluorescence due to preservation and storage. An average of $62 \%(\mathrm{SD}=0.03, \mathrm{n}=10)$ of the cyanobacteria pass the $934-\mathrm{AH}$ filter. For most samples, no red fluorescing cells were observed in the 934 AH filtrate. Some samples did have small eukaryotes present but their estimated biomass never exceeded $10 \%$ of the cyanobacterial biomass for the sample. This size fractionation technique is a useful procedure for separating coccoid cyanobacteria from the total photoautotrophic population. No fluorescing cells were observed in the Millipore HA filtrate. The same preparation for whole seawater revealed both cyanobacteria and red fluorescing eucaryotes.

Direct cell counts of cyanobacteria found in the Whatman $934 \mathrm{AH}$ filtrate and the difference in primary production retained on the 2 filter types allowed an estimate of the rate of carbon fixation per cell. The relative contribution by cyanobacteria to total primary production was determined by dividing the difference in values for the 2 filters by the fraction of cyanobacteria which passed the 934-AH filter. Cyanobacteria cellular photosynthetic response to different irradiances for a surface and a $105 \mathrm{~m}$ sample are shown in Fig. 3, demonstrating that surface populations were saturated, but not inhibited, by light levels typical of the upper euphotic zone. This implies that coccoid cyanobacteria may contribute significantly to primary production throughout the euphotic zone. The P-I curve for cyanobacteria from the chlorophyll maximum $(105 \mathrm{~m})$ demonstrated inhibition above $150 \mu$ Einst $m^{-2} s^{-1}$ (Fig. 3). Interpolation at the appropriate light level on P-I curves for samples from different depths allows an estimate of the cellular photosynthetic rate at specific depths. The cyanobacteria at the study site were dominated by coccoid forms with diameters ranging from 0.8 to $1.2 \mu \mathrm{m}$. Because of inherent inac- 


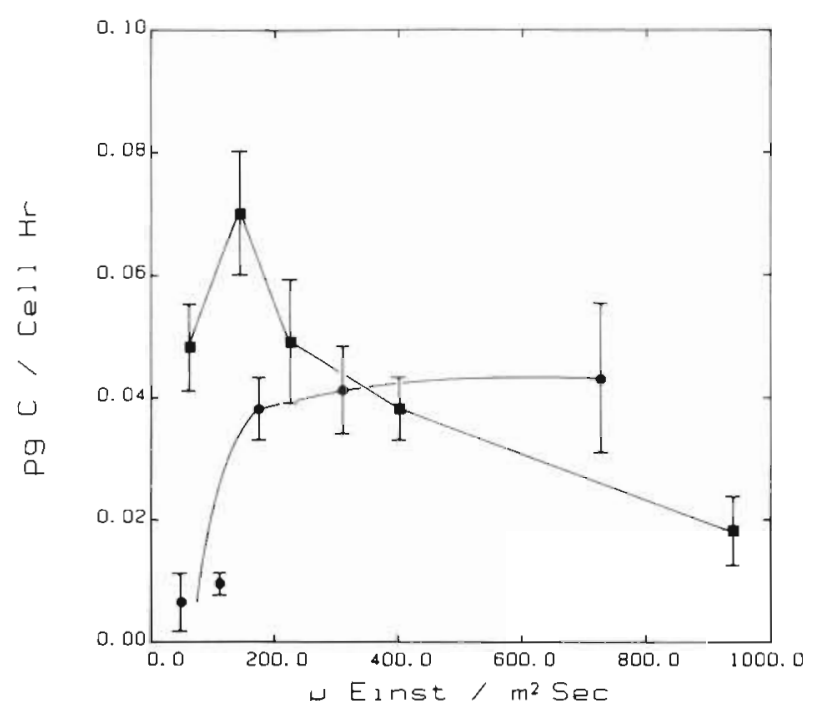

Fig. 3. Cyanobacteria cellular carbon incorporation as a function of irradiance for samples from the surface $(\bullet)$ and the chlorophyll maximum ( $\mathbf{m}$. Each value is the mean of duplicate samples, error bars represent the standard deviation of the mean

curacies associated with estimation of dimensions of fluorescing particles of such small size (halo effects, lower limit of optical microscopy resolution, inaccuracies of calibration of ocular micrometer) we have chosen to use the median diameter of $1.0 \mu \mathrm{m}$ for calculation of cell volumes.

Cyanobacteria growth rates were determined by the equation:

$$
\mathrm{u}=\ln \left[\left(\mathrm{C} \operatorname{cell}^{-1}+\Delta \mathrm{C} \operatorname{cell}^{-1} \mathrm{~d}^{-1}\right) / \mathrm{C} \mathrm{cell}^{-1}\right]
$$

where $C$ symbolizes carbon; $u$ has units of $d^{-1}$. For these estimates we assumed a cellular carbon concentration of $0.121 \mathrm{pg} \mathrm{C} \mu \mathrm{m}^{-3}$ (Watson et al. 1977, Douglas 1984). Our values for u are probably an upper limit since dark respiration cannot be determined by these standard photosynthetic techniques (Williams et al. 1983, Marra \& Heinemann 1984, Smith et al. 1984).

The quantum yield of photosynthesis, $\Phi$, is defined as moles of carbon fixed per mole of quanta absorbed (Rabinowitch \& Govindjee 1969). A general expression for $\Phi$ in terms of cellular photosynthetic and light data is:

$$
\Phi=\frac{\frac{\text { moles } C}{\text { cell } \times \text { time }}}{Q \times \frac{\text { Einst }}{\text { area time }} \times \frac{\text { cross-sectional area }}{\text { cell }}}
$$

The cellular absorption efficiency, $Q$, is defined as the ratio of quanta absorbed by a cell divided by the total quanta which intercept the cell's geometric cross-sec- tion (Morel \& Bricaud 1981). We determined $Q$ for a phycoerythrin containing Synechococcus sp. (DC-2, Bigelow laboratory culture collection) according to techniques described elsewhere (Mitchell \& Kiefer 1984). DC-2 in culture has an average cell diameter greater than cells observed in nature. We scaled the value of $Q$ for $D C-2$ to a value appropriate for the cell diameters of the natural population. This procedure assumes that the intercellular pigment concentration (per unit volume) is the same for DC-2 and natural cells. Using this scaled value of $Q$ and the initial slope of the photosynthesis-irradiance curves, we estimated the quantum yield of photosynthesis. A mean value of $0.08 \pm 0.03$ mole carbon (Einst absorbed) ${ }^{-1}$ indicated that the cyanobacteria in this study were photosynthesizing near the maximal yield for phytoplankton reported by Bannister \& Weidemann (1984).

Grazing experiments were conducted by adding ${ }^{14} \mathrm{C}$ labeled DC-2 (WH 7803) cells to seawater and incubating in the dark for $24 \mathrm{~h}$ at in situ temperatures. DC-2 was grown axenically with $\mathrm{H}^{14} \mathrm{CO}_{3}^{-}$(approx. $1 \mu \mathrm{Ci}$ $\mathrm{ml}^{-1}$ ) in $\mathrm{f} / 2$ media (Guillard 1975) with continuous illumination (15 $\mu$ Einst $\left.\mathrm{m}^{-2} \mathrm{~s}^{-1}\right)$. Cells were harvested after stationary phase was reached, in order to minimize small molecular pools (Taylor \& Sullivan 1984). Cells were centrifuged $\left(6 \times \mathrm{g}\right.$ at $\left.4^{\circ} \mathrm{C}\right)$, and washed with ice cold filtered $(0.2 \mu \mathrm{m})$ and autoclaved sea water until no residual inorganic $\mathrm{H}^{14} \mathrm{CO}_{3}^{-}$was found in the rinse supernatant. The final cell suspension was kept dark on ice until use. The specific activity per cell was determined by direct cell counts and liquid scintillation. No loss of activity was observed for cells stored over a month under such conditions.

In the grazing experiments, we added 3 different concentrations of ${ }^{14} \mathrm{C}$-labeled $\mathrm{DC}-2$ to natural water samples. The concentrations of labeled cells added ranged from 10 to $40 \%$ of the natural cyanobacterial population, previously determined by epifluorescent microscopy. Micrograzers were recovered on $8.0 \mu \mathrm{m}$ Nuclepore filters by vacuum filtration $(<2.5 \mathrm{~mm} \mathrm{Hg})$ with 4 subsequent rinses of $100 \mathrm{ml}$ filtered seawater $(0.45 \mu \mathrm{m}$ Millipore HA). To avoid filter clogging, each sample $(1000 \mathrm{ml})$ was filtered after incubation in aliquots of $200 \mathrm{ml}$ each. The set of filters for each sample was placed in a scintillation vial containing $0.5 \mathrm{ml}$ of Protosol (New England Nuclear). After $14 \mathrm{~h} 10 \mathrm{ml}$ of Scint-A (Packard) was added. Samples were quench corrected by the external standard ratio technique. Grazing rates were determined after subtracting the counts measured for a time zero control from the counts of the incubated samples. The mean for the 3 concentrations was considered the representative rate. No saturation of grazing was evident at the higher concentrations, which agrees with dilution culture experiments (Landry et al. 1984). 
Grazing losses were determined by the equation:

$$
g=\ln \left|\frac{1}{1-\frac{\mathrm{CPM}_{\mathrm{G}}}{\mathrm{CPM}_{\mathrm{T}}}}\right|
$$

where $\mathrm{CPM}_{\mathrm{T}}=$ total ${ }^{14} \mathrm{C}$-Synechococcus label added; $\mathrm{CPM}_{\mathrm{G}}=$ grazer label retained on the $8.0 \mu \mathrm{m}$ filter after a $24 \mathrm{~h}$ incubation in the dark at in situ temperatures; $\mathrm{g}$ has units $d^{-1}$. These rates are probably an underestimate of the natural grazing rates due to small grazer loss and large grazer avoidance of the Niskin sampling bottles. In addition grazer excretion and respiration of metabolized label was not determined.

Fig. 2 and Table 1 summarize the vertical distribution of the data. These data indicate that cyanobacterial production and consumption by grazers are highest near the deep chlorophyll maximum, which agrees with previous reports for picoplankton (Morris \& Glover 1981, Li et al. 1983, Platt et al. 1983). However, the mean growth rate for 3 samples from the mixed layer suggests that cyanobacteria can adapt to higher irradiances.

Microautoradiography (Hoppe 1977) revealed that a broad diversity of grazers ingest and effectively metabolize the cyanobacteria (Fig. 4). Protozoa, primarily, show effective metabolic utilization of cyanobacteria as a food source as indicated by the uniform distribution of the exposed silver grains in the microautoradiographs. Most of the observed cyanobacterial grazers ranged in size from 10 to $50 \mu \mathrm{m}$ although an unidentified grazer $300 \mu \mathrm{m}$ in length clearly shows uniform cytoplasmic labeling (Fig. 4, middle right). High silver grain density in the cephallic region of a chaetognath (Fig. 4, lower right), which are strictly carnivorous (Feigenbaum \& Maris (1984), suggests a rapid ( $\leq 1 \mathrm{~d}$ ) trophic transfer from cyanobacteria to higher levels of the pelagic food web. Efficient trophic transfer from the cyanobacteria to camivores may be mediated by large protozoans which could represent a direct link between the smallest photoautotrophs and traditionally recognized primary carnivores. A calanoid copepodite concentrated the labeled cells in a hind gut fecal pellet, indicating the ability to ingest but not metabolize cyanobacteria, as previously reported (Johnson et al. 1982). Grazing losses due to copepods may not represent transfer to higher trophic levels within the epipelagic zone, but cyanobacteria within sinking fecal pellets may be of significance to the food web of the mesopelagic zone. These results are the initial documentation of a diverse group of grazers capable of mediating the trophic transfer of cyanobacterial primary production in the ocean.

Table 2 summarizes recent field studies of the picoplankton, or cyanobacteria. With the exception of the growth rates reported by Platt et al. (1983), our data agree with previous reports, but suggest that cyanobacteria, specifically, are the dominant contributor to the photosynthetic picoplankton in oligotrophic systems. Since Platt et al. (1983) estimated autotrophic carbon from particulate carbon determinations, their approach may have underestimated detrital carbon, resulting in lower estimated growth rates. The relatively high abundance of cyanobacteria in the open ocean has been well documented (Johnson \& Sieburth 1979, Waterbury et al. 1979). The high growth rates indicated by Table 2 imply that cyanobacteria play a significant role in the food web dynamics of the open ocean. These conclusions support the hypothesis of rapid growth in nutrient-depleted conditions. This concept requires a rapid turnover of biomass to supply an adequate nutrient flux (McCarthy \& Goldman 1979), and to maintain observed ecosystem stability (Hayward et al. 1983). Little information has been reported regarding the grazing upon cyanobacteria (Johnson et al. 1982, Landry et al. 1984) which must balance their high growth rates. The use of radiolabeled cyanobacteria has allowed, for the first time, photographic documentation of micrograzers which

Table 1. Vertical distribution of photosynthetic, growth and grazing data. Values are means for replicate samples; errors are standard deviations of the mean. n: number of replicates

\begin{tabular}{|c|c|c|c|c|c|c|c|}
\hline $\begin{array}{l}\text { Depth } \\
\text { (m) }\end{array}$ & $\begin{array}{c}\% \text { Surface } \\
\text { irradiance } \\
(488 \mathrm{~nm})\end{array}$ & $\begin{array}{l}\text { Total } \\
\text { chiorophyll a } \\
\mathrm{mg} \mathrm{m}^{-3}\end{array}$ & $\begin{array}{l}\text { Total } \\
\text { photosynthesis } \\
m g C \mathrm{~m}^{-3} \mathrm{~d}^{-1}\end{array}$ & $\begin{array}{c}\text { Assimilation } \\
\text { number } \\
\operatorname{mgC}(\operatorname{mg} C h l a)^{-1} h^{-1}\end{array}$ & $\begin{array}{c}\text { \% Photosynthesis } \\
\text { attributed to } \\
\text { cyanobacteria }\end{array}$ & $\begin{array}{l}\text { Cyanobacterid } \\
\text { growth rate. } u \\
d^{-1}\end{array}$ & $\begin{array}{c}\text { Cyanobacteria } \\
\text { grazing loss, } g \\
d^{-i}\end{array}$ \\
\hline $\begin{array}{l}\text { Mixed } \\
\text { layer }\end{array}$ & 35 & $\begin{aligned} 0.127 & \pm .002 \\
n & =6\end{aligned}$ & $\begin{array}{c}3.15 \pm 0.31 \\
n=4\end{array}$ & 2.1 & 56 & $\begin{array}{c}1.3 \pm 0.4 \\
n=4\end{array}$ & $\begin{aligned} 0.2 & \pm 0.15 \\
n & =3\end{aligned}$ \\
\hline 75 & 8 & $\begin{array}{c}0.190 \pm .001 \\
n=2\end{array}$ & $\begin{array}{c}2.6 \pm 020 \\
n=2\end{array}$ & 114 & 50 & $\begin{array}{c}1.7 \pm 0.35 \\
n=2 .\end{array}$ & na \\
\hline 90 & 5 & $\begin{array}{c}0.230 \pm .001 \\
n=2\end{array}$ & $\begin{array}{c}3.5 \pm 0.25 \\
n=2\end{array}$ & 1.3 & 80 & na & $\begin{aligned} 0.4 & \pm 0.12 \\
n & =3\end{aligned}$ \\
\hline 105 & 2.5 & $\begin{array}{c}0490 \pm .004 \\
n=2\end{array}$ & $\begin{aligned} 3.8 & \pm 0.30 \\
n & =2\end{aligned}$ & 0.65 & 45 & $\begin{array}{c}2.3 \pm 0.4 \\
n=2\end{array}$ & na \\
\hline
\end{tabular}



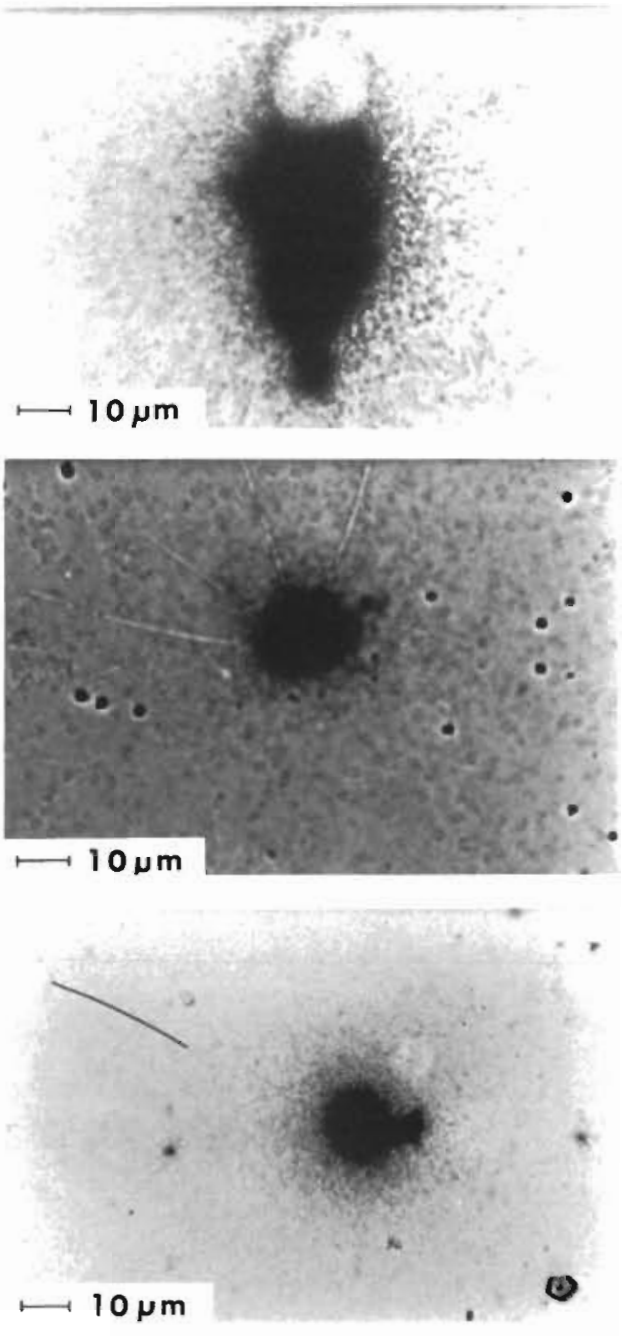

Fig. 4. Microautoradiographs showing a broad diversity of micrograzers which consumed ${ }^{14} \mathrm{C}$ labeled Synechococcus sp., including Protozoa, a copepod larva (bottom left) and a chaetognath (bottom right). The uniform distribution of the label in most of the organisms indicates effective metabolic utilization. The copepod larva has concentrated labeled cells in a hind gut fecal pellet, suggesting non-utilization. Utilization of cyanobacteria by relatively large grazers (middle right) suggests a mechanism for efficient trophic transfer to larget carnivores

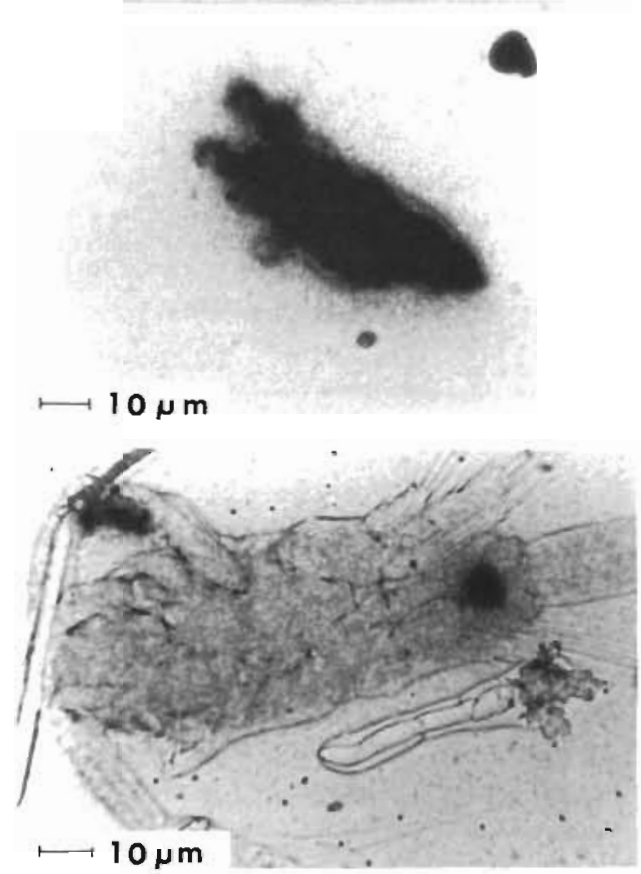

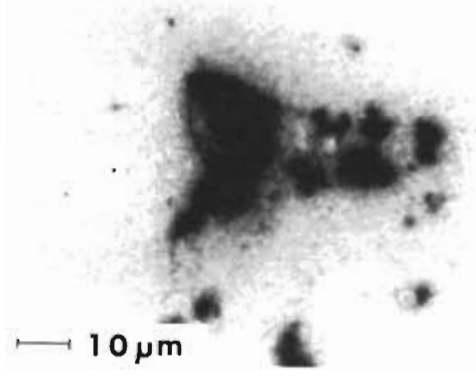
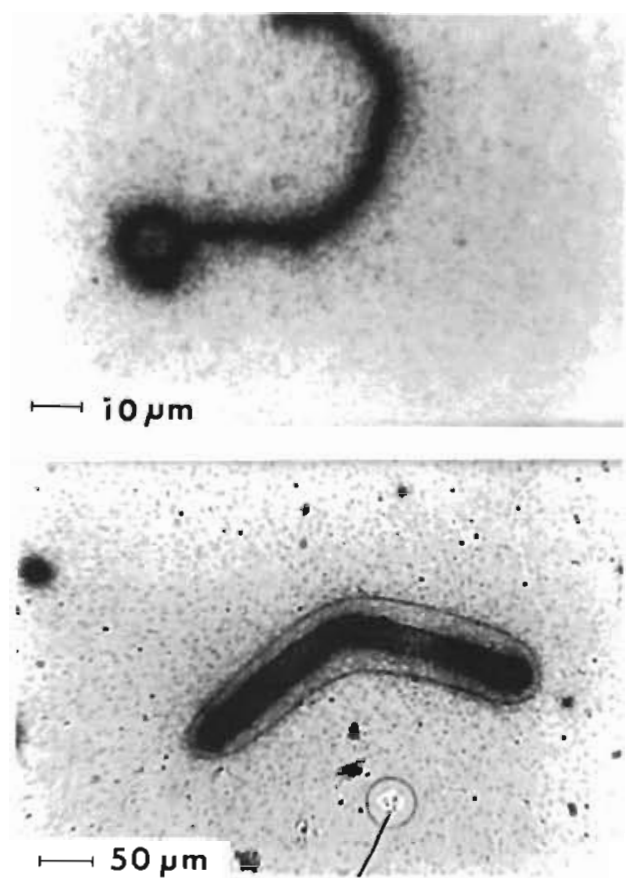
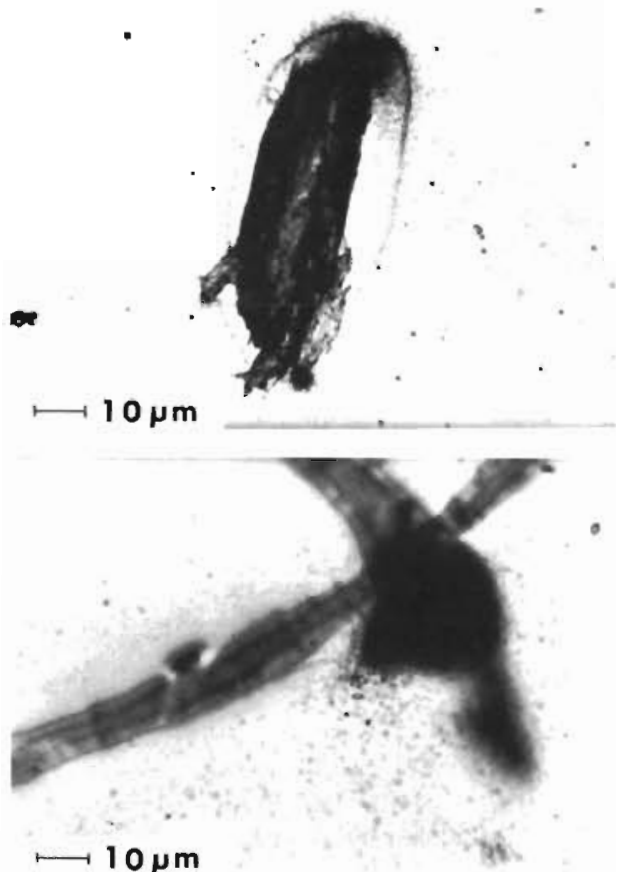
Table 2. Recent reports of the contribution of picoplankton or cyanobacteria to marine trophodynamics. Values of u and g are the daily specific exponential rates for growth and grazing as defined in the text. Values are means for replicate samples; errors are standard deviation of the mean. $n$ : number of samples

\begin{tabular}{|c|c|c|c|c|c|}
\hline Source & $\begin{array}{l}\text { Size fraction } \\
\text { measured }\end{array}$ & $\begin{array}{c}\% \text { Contribution } \\
\text { to primary } \\
\text { production }\end{array}$ & $\begin{array}{c}\text { Specific } \\
\text { growth, } u \\
d^{-1}\end{array}$ & $\begin{array}{c}\text { Specific } \\
\text { grazing, } g \\
d^{-1}\end{array}$ & $\begin{array}{c}\text { Quantum yield } \\
\text { Mole carbon } \\
\text { Einstein absorbed }\end{array}$ \\
\hline $\begin{array}{l}\text { Bienfang \& Takahashi (1983) } \\
\text { Takahashi \& Bienfang (1983) }\end{array}$ & $<3.0 \mu \mathrm{m}$ & $80^{\circ}$ & $\begin{array}{l}1.2 \pm 0.33 \\
\mathrm{n}=2\end{array}$ & na & na \\
\hline Li et al. (1983) & $<1.0 \mu \mathrm{m}$ & $\begin{array}{r}44 \pm 3 \\
\mathrm{n}=2\end{array}$ & na & na & na \\
\hline Platt et al. (1983) & $<1.0 \mu \mathrm{m}$ & $60^{\circ}$ & $0.15^{\circ}$ & na & na \\
\hline Douglas (1984) & $<1.0 \mu \mathrm{m}$ & $\begin{aligned} 30 & \pm 10 \\
n & =5\end{aligned}$ & $\begin{aligned} 1.5 & \pm 0.3 \\
n & =2\end{aligned}$ & na & na \\
\hline Landry et al. (1984) & Cyanobacteria & na & $\begin{array}{c}1.7 \pm 0.3 \\
n=2\end{array}$ & $\begin{aligned} 0.26 & \pm 0.12 \\
\mathrm{n} & =2\end{aligned}$ & nа \\
\hline This study & Cyanobacteria & $\begin{aligned} 64 & \pm 6 \\
\mathrm{n} & =28\end{aligned}$ & $\begin{array}{l}1.6 \pm 0.3 \\
n=5\end{array}$ & $\begin{array}{l}0.3 \pm 0.1 \\
\mathrm{n}=6\end{array}$ & $\begin{aligned} 0.08 & \pm 0.03 \\
\mathrm{n} & =5\end{aligned}$ \\
\hline
\end{tabular}

consume and metabolize cyanobacteria in the field. Although quantification with our technique represents a lower limit for grazing losses for cyanobacteria, our data indicate that at least 30 to $40 \%$ of the cyanobacteria standing crop is consumed daily. Due to the fragility and small size of the Protozoa, which appear to dominate the grazing of cyanobacteria, they have probably been significantly underestimated in microscopic counts (Beers et al. 1982, Haas 1982, Hewes et al. 1984). Traditional field techniques have apparently overlooked the significance of a picoplankton-microzooplankton trophic link (Johnson et al. 1982, Sieburth \& Davis 1982), which exists in addition to the classical oceanic food web paradigm (Steele 1974) of larger phytoplankton (e.g. diatoms, dinoflagellates) consumed by larger zooplankton (e.g. copepods). Current revisions of pelagic ecosystem structure have included a 'microbial loop' consisting of Protozoa which graze on bacterioplankton secondary production (Pomeroy 1974, Williams 1981, Azam et al. 1983). Recent reports documenting high cyanobacterial primary production rates, and our demonstration of an active community of cyanobacterial grazers, support their inclusion in conceptual models of ecosystem structure (Johnson et al. 1982). From the results of this study, we postulate that the lowest trophic level of the oligotrophic ocean food web dominates biomass rate processes and includes a diverse microzooplankton population that is largely supported by the chroococcoid cyanobacteria.

Acknowledgements. This work was sponsored by the Office of Naval Research grant N00014-81-K-0388. We wish to thank D. Kiefer, J. Mueller and R. Zaneveld for their support and encouragement.

\section{LITERATURE CITED}

Azam, F., Fenchel, T., Field, J. G., Gray, J. S., Meyer-Reil, L. A., Thingstad, F. (1983). The ecological role of watercolumn microbes in the sea. Mar. Ecol. Prog. Ser 10: $257-263$

Bannister, T T., Weidemann, A. D. (1984). The maximum quantum yield of phytoplankton photosynthesis in situ. J. Plankton Res. 6: 275-294

Beers, J. R., Reid, F. M. H., Stewart, G. L. (1982) Seasonal abundance of the microplankton population in the North Pacific Central gyre. Deep Sea Res. 29: 227-245

Bienfang, P. K., Takahashi, M. (1983). Ultraplankton growth rates in a subtropical ecosystem. Mar. Biol. 76: 213-218

Douglas, D. J. (1984). Microautoradiography-based enumeration of photosynthetic picoplankton with estimates of carbon-specific growth rates. Mar Ecol. Prog. Ser. 14: 223-228

Feigenbaum, D. L., Maris, R. C. (1984). Feeding in the Chaetognatha. Oceanogr. mar. Biol. A. Rev. 22: 343-392

Guillard, R. R. L. (1975). Culture of phytoplankton for feeding marine invertebrates. In: Smith, $W$ L., Chanely, M. $H$. (ed.) Culture of marine invertebrate animals. Plenum Press, New York, p. 29-60

Haas, L. W. (1982). Improved epifluorescence microscopy for observing planktonic microorganisms. Annls Inst. océanogr., Paris 58(S): 261-266

Hayward, T. L., Venrick, E. L., McGowan, J. A. (1983). Environmental heterogeneity and plankton community structure in the central North Pacific. J. mar. Res. 41: 711-729

Hewes, C. D., Reid, F. M. H., Holm-Hansen, O. (1984). The quantitative analysis of nanoplankton: A study of methods. J. Plankton Res. 6: 601-613

Hoppe, H. G. (1977). Analysis of actively metabolizing bacterial populations with the autoradiographic method. In: Rheinheimer, G. (ed.) Microbial ecology of a brackish water environment. Ecological Studies 25. Springer, New York, p. 179-197

Johnson, P. W., Sieburth, J. M. (1979). Chroococcoid cya- 
nobacteria in the sea: A ubiquitous and diverse phototrophic biomass. Limnol. Oceanogr 24: 928-935

Johnson, P. W., Huai-Shu, X., Sieburth, J. M. (1982). The utilization of chroococcoid cyanobacteria by marine protozooplankters but not by calanoid copepods. Annls Inst. océanogr., Paris 58(S): 297-308

Landry, M. R., Haas, L. W., Fagemess, V L. (1984). Dynamics of microbial plankton communities: experiments in Kaneohe Bay, Hawaii. Mar Ecol. Prog. Ser. 16: 127-133

Li, W. K. W., Subba Rao, D. V., Harrison, W. G., Smith, J. C. Cullen, J. J., Irwin, B., Platt, T. (1983). Autotrophic picoplankton in the tropical ocean. Science 219: 292-295

Marra, J., Heinemann, K. (1984). A comparison between noncontaminating and conventional incubation procedures in primary production measurements. Limnol. Oceanogr. 29: 389-392

McCarthy, J. J., Goldman, J. C. (1979). Nitrogenous nutrition of marine phytoplankton in nutrient depleted waters. Science 203: 670-672

Mitchell, B. G., Kiefer, D. (1984). Determination of absorption and fluorescence excitation spectra for phytoplankton. In: Holm-Hansen, O., Bolis, L., Gilles, R. (ed.) Marine phytoplankton and productivity. Springer, New York, p. $157-169$

Morel, A., Bricaud, A. (1981). Theoretical results concerning light absorption in a discrete medium, and application to specific absorption of phytoplankton. Deep Sea Res. 28: 1375-1393

Morris, I., Glover, H. (1981). Physiology of photosynthesis by marine coccoid cyanobacteria - some ecological implications Limnol. Oceanogr. 26: 957-961

Platt, T., Subba Rao, D. V., Irwin, B. (1983). Photosynthesis of picoplankton in the oligotrophic ocean. Nature, Lond. 301: 702-704

Pomeroy, L. R. (1974). The ocean's food web, a changing paradigm. Bioscience 24: 499-504

Rabinowitch, E., Govindjee (1969). Photosynthesis. John Wiley and Sons, New York

Sieburth, J. McN., Smetacek, V., Lenz, J. (1978). Pelagic ecosystems structure: Heterotrophic compartments of the plankton and their relations to plankton size fractions. Limnol. Oceanogr. 23: 1256-1263

Sieburth, J. MCN., Davis, P. G. (1982). The role of heterotrophic nanoplankton in the grazing and nurturing of planktonic bacteria in the Sargasso and Caribbean Seas. Annls Inst. océanogr. Paris 58(S): 285-286

Smith, R. E. H., Geider, R. J., Platt, T (1984). Microplankton productivity in the oligotrophic ocean. Nature, Lond 311: $252-254$

Steele, J. H. (1974). The structure of marine ecosystems. Harvard Univ. Press, Cambridge, Massachusetts

Strickland, J. D. H., Parsons, T. R. (1972). A practical handbook of sea water analysis. 2nd ed. Bull. Fish. Res. Bd Can. 167

Takahashi, M., Bienfang, P. K. (1983). Size structure of phytoplankton biomass and photosynthesis in subtropical Hawaiian waters. Mar. Biol. 76: 203-211

Taylor, G. T., Sullivan, C. W. (1984). The use of ${ }^{14} \mathrm{C}$-labeled bacteria as tracer of ingestion and metabolism of bacterial biomass by microbial grazers. J. microbiol. Methods 3: 101-126

Waterbury, J. B., Watson, S. W., Guillard, R. R. L., Brand, L. E. (1979). Widespread occurrence of a unicellular, marine, planktonic cyanobacterium. Nature, Lond. 277: 293-294

Watson, S. W., Novitsky, T. J., Quinby, I. C., Valois, F. W. (1977). Determination of bacterial number and biomass in marine environments. Appl environ. Microbiol. 33: 940-946

Williams, P. J. LeB. (1981). Incorporation of microheterotrophic processes into the classical paradigm of the planktonic food web. Kieler Meeresforsch. 5: 1-28

Williams, P. J. LeB., Heinemann, K., Marra, J., Purdie, D. A. (1983). Comparison of $14-\mathrm{C}$ and $\mathrm{O}_{2}$ measurements of phytoplankton production in oligotrophic waters. Nature, Lond. 305: 49-50

Accepted for printing on October 22, 1985 